\title{
Terrorism and Weapons of Mass Destruction: Has the Taboo Been Broken?
}

\author{
Brad Roberts Institute for Defense Analyses, USA
}

W ith the March 1995 nerve gas attack on the Tokyo subway and subsequent revelations about the larger chemical and biological warfare capabilities and ambitions of the Aum Shinrikyo sect, pundits have begun to make much of the event as a watershed, one that has broken a decades old taboo on the use of such weapons. How valid is this concern? Have we entered a new era in which terrorists will make increasing use of these and other weapons of mass destruction?

Jonathan Tucker's thoughtful review of the problem of chemical and biological terrorism offers many insights into these issues. His policy agenda is particularly germane at a time when the U.S. federal government is putting in place a new set of counterterrorism laws. In some valuable ways, Tucker's agenda goes well beyond what the government was able to cobble together for itself in the rush to respond to the outrage in Oklahoma City. The focus of this commentary, however, is on his discussion of "a new type of terrorist." Tucker's review of the political and technical barriers to terrorist use of chemical and biological weapons (CBW) and his concern about the growing number of religious cults with a propensity to messianic violence and about more virulent forms of state-sponsored terrorism are right on the mark. They also provide the basis for a more comprehensive assessment of future prospects.

In speculating about the future of CBW terrorism after the Tokyo incident, it is useful to separate the problem into at least two parts. One part is that posed by traditional terrorist actors (individuals or groups), who may see in CBW a new tool of warfare. The other part is that posed by new

Brad Roberts is a member of the research staff of the Institute for Defense Analyses, $1801 \mathrm{~N}$. Beauregard Street, Alexandria, VA 22091, USA (E-mail: BROBERTS@IDA.ORG). He is also chairman of the research advisory council of the Chemical and Biological Arms Control Institute and an adjunct professor at George Washington University. The vicws expressed here are his own and should not be attributed to any organization with which he is affiliated. He served previously as editor of The Washington Quarterly and as a research fellow at the Center for Strategic and International Studies in Washington, DC. Dr. Roberts has written extensively on issues of chemical and biological warfare and more generally on problems of national and intemational security after the Cold War. Recent publications include Biological Weapons: Wecipons of the Future? (Center for Strategic and International Studies, 1993), Orderand Disorder.Afier the ColdWar.(MIT Press, 1995), and Weapons Proliferation and World Order (Kluwer International Press, 1996). terrorist actors, who may see in CBW a suitable tool for new purposes.

Of the traditional terrorist actors, there are essentially three types. One is politically motivated groups that utilize violence to demand a seat at the political table and to establish the legitimacy of their cause. Such terrorist organizations must carefully calibrate the level of violence they employ-enough to underline their cause but not too much to undermine their legitimacy. This is arguably why organizations such as the Palestine Liberation Organization and the Irish Republican Army have seen weapons of mass destruction as counterproductive for their aims.

A second type of terrorist is found in politically motivated groups that utilize violence to invoke an overreaction by the state, thereby causing the people to rise up and cast off a comupt, authoritarian state. This is the terrorism of the Red Army Faction and the Baader-Meinhof Gang, for example. Groups such as these also have had to calibrate the level of violence. By and large, they failed to do so, creating more sympathy for a state crackdown on their behavior than for their cause.

The third type of terrorist is state-sponsored. These terrorists' violent ways are manipulated by foreign powers to gain political leverage within a state or region in the service of a global anti-status quo campaign. The violence that they employ must be calibrated by both the terrorist group, fearful of being tracked down and eliminated, and by the sponsoring state, fearful of being attacked in retribution for acts clearly attributed to it. Weapons of mass destruction have, so far at least, been seen as counterproductive for such terrorists.

The terrorism of all three types reflects a careful calculation of thresholds of pain and of tolerance in the targeted society for political gain through the use of violence. None has seen nuclear, biological, or chemical weapons as useful to its purposes. This suggests that important barriers to future use remain in place. Calculations of thresholds of pain and tolerance are not likely to have been sharply influenced by the Aum attack-if anything, the Aum attack might be read by such terrorists as demonstrating the firm state reactions demanded by such incidents.

But there are at least two important caveats to this assessment. First, terrorists seem increasingly to prefer indiscriminate types of attacks, as witnessed in recent years by the growing use of car bombings and suicide bombings in public places. Second, established terrorist groups have a noticeable tendency to mimic each other's behavior and to adopt 
strategies and tactics that they have seen employed elsewhere. Each of these factors may contribute to greater interest among traditional terrorist groups in chemical and/or biological weapons.

The other part of the future CBW terrorism problem is that posed by the emergence of new terrorist actors. Such actors are not necessarily bound by the political and technical constraints that, so far at least, have served to inhibit CBW terrorism, as Tucker rightly observes. The essential questions are whether there will be more such actors and whether $\mathrm{CBW}$ will appeal to these new actors. Again, there are three essential types.

The first type is state-sponsored terrorism in war or near-war situations. Such terrorists might use one or a few attacks with weapons of mass destruction to sow fear among the American public, hoping thus to generate political pressures in Congress that will induce the U.S. president to avoid military confrontation with the sponsoring state or to back down from such confrontation once begun. This form of terrorism may of course reflect a fundamental misreading of the American public, which is more likely to be enraged by such acts and to seek prompt and decisive removal of the offending regime than to cower in fear. For these terrorist purposes, nuclear weapons seem likely to appear unattractive (given the certainty of the response they would evoke from the United States), whereas chemical or biological weapons may appear less so, especially considering the plausible denial of responsibility a sponsoring state could make for any sudden outbreak of infectious diseases in the United States. A variant on this type of terrorism might be the use of such weapons in attacks on the populations of U.S. allies, in the belief that those allies would pressure the United States to capitulate

The sccond type is terrorism motivated by the desire to strike a crippling blow against a hated enemy. Such terrorism may well be the act of one or two individuals and not of a group or state. Possible targets and purposes are numerous. These might be acts of "sacred terror" against symbols of corrupt power on earth; they might be strikes against despised ethnic groups; they might be calculated attempts to disrupt the economy or political institutions of decaying imperialist states, in the hope of speeding their collapse; or, they might be acts of radical paranoia, aimed at fanciful enemies. They might also be acts of vengeance or righteousness, aimed not so much at crippling the target as at getting even. For such purposes, chemical and biological weapons might have a special appeal as particularly insidious and, in the case of infectious biological agents, essentially uncontrollable.

The third type is an act of mere criminality, brought to new heights of violence by the ever broader availability of scientific and technical expertise. These acts may hardly be considered terrorism per se, but rather acts of extortion or simple mass murder. But such acts of violence would certainly induce public terror, even if the actor did not intend to exploit terror for political purposes.

Of course, none of these types is really new. But organizations and individuals willing to exploit violence for these purposes appear to be growing in number in the 1990s. Moreover, people fear that those numbers will continue to grow in the decades ahead if developed countries continue to suffer social decay and if developing countries continue to suffer civil and international war (in addition to social decay). For all three types, calculations of pain thresholds and tolerances seem unlikely. Only for those in the first category is the use of violence aimed at extracting political concessions. For the latter two especially, chemical and biological weapons may seem attractive. They will certainly be technically within the reach of most or all terrorists.

So has the taboo been broken? The answer is yes and no. For traditional terrorist actors, important barriers remain to the use of weapons of mass destruction, as such weapons are fundamentally counterproductive for their intended goals. Even new groups that form in future years to press claims of legitimacy seem unlikely to embrace such weapons. But for nontraditional terrorist actors, the taboo may not be in the least bit relevant. But this is not also to predict that the foreseeable future will see a lot of CBW terrorism, or even a few instances generating many thousands of casualties. The policy agenda elaborated in Tucker's article promises to make a significant contribution to the amelioration of those risks-if it is fully implemented. 